\title{
DETERMINATION OF SOME BOTANICAL, PHENOLOGICAL, PHYSICAL AND CHEMICAL CHARACTERISTICS OF WALNUT (JUGLANS REGIA L.) GENOTYPES GROWN IN TURKEY
}

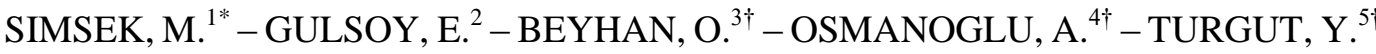 \\ ${ }^{1}$ Department of Horticulture, Faculty of Agriculture, Dicle University, 21280, Turkey \\ ${ }^{2}$ Department of Horticulture, Faculty of Agriculture, Igdir University, 76000, Turkey \\ ${ }^{3}$ Sakarya University, Pamukova Vocational School, 54900,Turkey \\ ${ }^{4}$ Department of Horticulture, Faculty of Agriculture, Bingol University, 12000, Turkey \\ ${ }^{5}$ Ministry of Food Agriculture and Livestock of Mardin Province, 47100, Turkey \\ ${ }^{\dagger}$ These authors contributed equally to this work. \\ *Corresponding author \\ e-mail: mikdat.simsek@dicle.edu.tr \\ (Received $11^{\text {th }}$ Jan 2017; accepted $16^{\text {th }}$ Mar 2017)
}

\begin{abstract}
Botanical, phenological, physical and chemical characteristics of promising walnut (Juglans regia L.) genotypes grown in the Beyazsu region (Mardin) of Turkey were studied during years 20122013. The physical properties of genotypes were attributed to the quality criteria of nuts. Fruit weight (Fw1), kernel weight (Kw), fruit length (Fl), fruit witdh (Fw2), fruit height (Fh), kerrnel ratio (Kr) and shell thickness (St) were determined as 9.67-15.68 g, 5.35-8.54 g, 5.35-8.54 g, 33.53-45.78 mm, 28.42$37.00 \mathrm{~mm}, 28.30-36.32 \mathrm{~mm}, 48.35-67.27 \%$ and $0.66-1.40 \mathrm{~mm}$, respectively. The kernel color (Kc) and fruit size (Fs2) were light yellow and ekstra of all the genotypes. The fruits were found to be rich in crude protein $(\mathrm{Cp})$ and crude oil $(\mathrm{Co})$. The total energy (Toe), moisture (Mo), total ash (Ta), crude oil (Co), crude protein (Cp) and total carbohydrate (Toc) contents were determined as 692.37-723.37 kcal., 3.11$3.98 \%, 1.30-2.09 \%, 62.25-68.91 \%, 14.92-18.27 \%$ and $10.21-16.15 \%$, respectively. Fruitful laterals (Frl) ranged from 40 to $90 \%$ while harvest date $(\mathrm{Hd})$ ranged from 10-15 September to 1-10 October. The flowering habits (Fh) observed as 6 protandrous, 6 protogynous and 2 homogamous of the promising genotypes. The results might contribute to breeding studies in order to identify better walnut genotypes, the commercial production for the farmers in the region, and healthy diets in future.
\end{abstract}

Keywords: tree properties, fruit properties, physicochemical characteristics, SPSS, Mardin

\section{Introduction}

The Persian walnut (Juglans regia L.) is one of the most horticulturally developed and widely cultivated walnut species (Akca et al., 2012). This plant is native to central Asia and grows as a wild or semi-cultivated tree in a wide area from southeastern Europe and the Caucasus to Turkey and Iran, through southern portions of the former Soviet Union into China and the eastern Himalayas (Ercisli et al., 2011).

Turkey ranks fourth in the world with a production of 212.140 tons (FAO, 2013), which is mostly from spontaneously growing trees, but the cultivation of new walnut cultivars from selective breeding programs will lead to commercially competitive walnut production (Koyuncu et al., 2004; Simsek et al., 2010). Therefore, in Turkey the 
researches on walnut genotypes and cultivars have been ongoing and their production is being encouraged to increase its world market share.

Turkish Standard Institute established physical chaacteristics of walnut as a quality criteria (TSE, 1990; TSE, 1991). The chemical compositions of walnut ranged from 13.60-18.10\% crude protein (Cp), from 62.60 to 70.30\% crude oil (Co) (Savage, 2001) and from 682 to $728 \mathrm{kcal}$ energy (Yerlikaya et al., 2012). Moreover, Ozkan and Koyuncu (2005) reported the chemical compositions of 10 walnut genotypes as follows: crude protein (Cp); 15.17-19.24\%, total ash (Ta); 1.26 to $2.06 \%$, crude oil (Co); 61.9770.92\%, moisture (Mo); 3.25-3.91\%, and total carbohydrate (Toc); 8.05-13.23\%.

Many studies have been carried out especially dealing with the phenological, botanical, physical and chemical characteristics of walnuts types and cultivars grown in different areas of Turkey (Askin and Gun, 1995; Bakkalbasi et al., 2010; Kazankaya et al., 2008; Koyuncu et al., 2004; Muradoglu and Balta, 2010; Oguz and Askin, 2007; Unver and Celik, 2005; Polat et al., 2015; Simsek, 2010a). However, there is no any reported previous study conducted in this microclimate area, Beyazsu region. The present study was of significant importance in achieving high quality walnut production for a sustainable and competitive market share. Therefore, it was aimed to determine some phenological, botanical, physical and chemical properties, resistant to anthrachnosis (Gnomonia leptostila), bacterial blight (Xanthomonas juglandis) and codling moth (Cydia pomonella) of the walnut genotypes grown in this region.

\section{Materials and Methods}

\section{Materials}

This study was carried out in Beyazsu region (Mardin) of Turkey between the years 2012-2013. It has been estimated that the research region has around 1000 walnut genotypes propagated naturally by seed. Study area is situated between $37^{0} 16^{1} 3.23^{11} \mathrm{~N}$ $41^{0} 18^{1} 4.60^{11} \mathrm{E}$ coordinates in the North and $37^{0} 5^{1} 52.84^{11} \mathrm{~N}-14^{0} 42^{1} 5^{11} \mathrm{E}$ coordinates in the South, at altitude ranging from 350 to 1000 meters asl (Anonymous, 2016). The walnut trees were at various ages, but not younger than 20 years old. In the research area, average annual temperature and precipitation are $16.6^{\circ} \mathrm{C}$, and $648 \mathrm{~mm}$, respectively (Anonymous, 2015). In the present study, 14 promising genotypes were purposively selected among the walnut trees and used as plant material in 2 consecutive years.

\section{Botanical and phenological characteristics}

Botanical and phenological characteristics of 14 promising walnut genotypes were observed and/or measured according to the method reported by Akca and Ozongun (2004), Bakkalbasi et al. (2010) and Simsek (2010a). Botanical characteristics such as tree habit, density of branch, vigour, age (estimated year), trunk circumference and brancing height were determined. The fruitful laterals (Frl), the tolerance to diseases and pests of all the genotypes were investigated. Phenological characteristics such as date of the first foliation (Dff), Flower habits (Fh), blooming date of male flowers (Bdmf), blooming date of female flowers (Bdff), date of the first budding (Dfb), date of full flowering (Dff) and Harvest date (Hd) observed. Walnut samples were collected from the selected 14 trees according to completely randomized experimental design with 3 replications and 30 fruits per tree for each year. The walnut trees received no cultural practices such as fertilization, irrigation, plant protection, etc. 


\section{Physical characteristics}

Physical measurements of fruits were carried out after drying in the shade. Features such as fruit weight $(\mathrm{Fw} 1)$, kernel weight $(\mathrm{Kw})$, kernel ratio $(\mathrm{Kr})$, shell thickness $(\mathrm{St})$, Fruit length (Fl), fruit width (Fw2), fruit height $(\mathrm{Fh})$ and other characteristics were determined according to the UPOV standards (Anonymous, 1994). While weighing was performed with sensitive precision scales, measuring was made with $0.01 \mathrm{~mm}$ precision digital caliper.

\section{Chemical characteristics}

Walnut kernels of the genotypes were grinded and Mo was determined before chemical analysis. Samples were dried in shadow for one week prior to determination of the Mo content, which was calculated by subtracting the dry weight from fresh weight (TSE, 1991). Crude protein $(\mathrm{Cp})$ content $(\mathrm{N} \times 6.25)$ was determined by using kjeldahl method (Jung et al., 2003). Prior to total ash (Ta) calculation samples were kept at $105^{\circ} \mathrm{C}$ for $24 \mathrm{~h}$ in an oven and then exposed to a muffle furnace (AOAC, 1990). The temperature was gradually raised to $600^{\circ} \mathrm{C}$ and the samples were ashed for $10-12 \mathrm{~h}$ to a white colour. Crede oil (Co) content was determined by extracting $8 \mathrm{~g}$ dried, grounded kernels per replicate with petroleum ether using a soxhlet apparatus at $45-50^{\circ} \mathrm{C}$ for $8-9$ h. The Crude oil (Co) content was detected as the difference in weight of dried kernel sample before and after the extraction according to AOAC (1995). Total carbohydrate (Toc) was calculated by subtracting other nutrient contents from total weight. Total energy (Toe) values were calculated by multiplying the amounts of Crude protein (Cp) in and total carbohydrate (Toc) by the factor of $4 \mathrm{kcal} / \mathrm{g}$ and Crude oil (Co) by the factor of $9 \mathrm{kcal} / \mathrm{g}$.

\section{Statistical analysis}

Analyses of physical and chemical characteristics were performed in triplicate on walnut genotypes for subsequent two years. All data were subjected to analysis of variance with the aid of SPSS (ver. 18).

\section{Results}

The fruitful laterals (Frl) ranged from 40 for MBSU121 and MBSU143 to 90\% for MBSU83, the promising genotypes (Table 1). The tree habit (Th) of walnut genotypes were determined as erect, semi-erect, semi-spreading and spreading; density of branch ( $\mathrm{Db})$ was determined as very sparse, sparse, dense and medium; vigour (V) was determined as strong, medium and weak. In addition, trunk circumference (Tc) ranged from 85 to $160 \mathrm{~cm}$. Moreover, the altitude (A), brancing height (Bh) and age (estimated year) (Aey) of the promising genotypes ranged from 475 to 625 meters, from 700 to $1300 \mathrm{~cm}$ and from 30 to 80 years, respectively (Table 1). In addition, The promosing walnut genotypes were resistant to anthrachnosis (Gnomonia leptostila), bacterial blight (Xanthomonas juglandis) and codling moth (Cydia pomonella). 
Table 1. Some botanical characteristics, fruitful laterals and altitudes of the promosing walnut genotypes (average 2012-2013)

\begin{tabular}{lcccccccc}
\hline Genotype & Th & Db & V & A (ey) & Tc (cm) & Fl(\%) & Bh(cm) & A(m) \\
\hline MBSU14 & Ss & Sp & St & 50 & 160 & 50 & 1200 & 475 \\
MBSU37 & S & M & M & 45 & 100 & 70 & 850 & 548 \\
MBSU44 & Se & D & W & 50 & 120 & 70 & 850 & 604 \\
MBSU53 & E & M & St & 35 & 95 & 60 & 850 & 556 \\
MBSU79 & S & Sp & St & 40 & 95 & 50 & 950 & 493 \\
MBSU83 & E & M & M & 65 & 115 & 90 & 1000 & 565 \\
MBSU95 & S & D & W & 50 & 85 & 80 & 800 & 534 \\
MBSU100 & Ss & M & M & 80 & 135 & 70 & 1300 & 530 \\
MBSU113 & O & Sp & St & 40 & 145 & 60 & 850 & 612 \\
MBSU121 & Se & Sp & St & 40 & 100 & 40 & 800 & 598 \\
MBSU128 & S & D & W & 20 & 90 & 70 & 700 & 625 \\
MBSU130 & S & D & W & 50 & 130 & 60 & 1100 & 596 \\
MBSU134 & Se & Sp & St & 35 & 125 & 50 & 1100 & 480 \\
MBSU143 & E & Vs & St & 25 & 95 & 40 & 950 & 540 \\
\hline
\end{tabular}

S: Spreading, Ss: Semi-spreading, Se: Semi-erect, E: Erect, O: Open, Sp: Sparse, Vs: Very sparse, M: Medium, D: Dense, St: Strong, W: Weak, Th: Tree habit, Db: Density of branch, V: Vigour, A (ey): Age (estimated year), Tc: Trunk circumference, Frl: Fruitful laterals, Bh: Brancing height, A: Altitude

The date of the first foliation (Dff), blooming date of male flowers (Bdmf), blooming date of female flowers (Bdff), date of the first budding (Dfb), date of full flowering (Dff) and Harvest date (Hd) of the genotypes ranged from 20 March to 2 April, from 30 March to 10 April, from 30 March to 15 April, from 26 March to 13 April, from 3 April to 20 April and from 10 September to 10 October, respectively (Table 2). In addition, it was determined that the Flower habits (Fh) observed as 6 protandrous, 6 protogynous and 2 homogamous of the promising genotypes. In this study, the genotypes with early foliation were eliminated (Table 2).

Table 2. Some phenological characteristics of promosing walnut genotypes

\begin{tabular}{lccccccc}
\hline Genotype & Dff & Fh & Bdmf & Bdff & Dfb & Dff & Hd \\
\hline MBSU14 & $20-21 \mathrm{M}$ & PD & $30 \mathrm{M}$ & $6 \mathrm{~A}$ & $4-5 \mathrm{~A}$ & $12-13 \mathrm{~A}$ & $10-5 \mathrm{~S}$ \\
MBSU37 & $21-22 \mathrm{M}$ & PG & $1 \mathrm{~A}$ & $30 \mathrm{M}$ & $26-7 \mathrm{M}$ & $4-5 \mathrm{~A}$ & $15-0 \mathrm{~S}$ \\
MBSU44 & $23-24 \mathrm{M}$ & PD & $30 \mathrm{M}$ & $8 \mathrm{~A}$ & $4-5 \mathrm{~A}$ & $13-14 \mathrm{~A}$ & $25-0 \mathrm{~S}$ \\
MBSU53 & $29-30 \mathrm{M}$ & PG & $9 \mathrm{~A}$ & $6 \mathrm{~A}$ & $3-4 \mathrm{~A}$ & $14-15 \mathrm{~A}$ & $1-10 \mathrm{O}$ \\
MBSU79 & $29-30 \mathrm{M}$ & PD & $7 \mathrm{~A}$ & $15 \mathrm{~A}$ & $10-11 \mathrm{~A}$ & $17-18 \mathrm{~A}$ & $25-0 \mathrm{~S}$ \\
MBSU83 & $22-23 \mathrm{M}$ & PG & $1 \mathrm{~A}$ & $30 \mathrm{M}$ & $27-8 \mathrm{M}$ & $3-4 \mathrm{~A}$ & $10-5 \mathrm{~S}$ \\
MBSU95 & $29-30 \mathrm{M}$ & PG & $8 \mathrm{~A}$ & $5 \mathrm{~A}$ & $2-3 \mathrm{~A}$ & $13-14 \mathrm{~A}$ & $1-10 \mathrm{O}$ \\
MBSU100 & $30-31 \mathrm{M}$ & HO & $10 \mathrm{~A}$ & $10 \mathrm{~A}$ & $9-11 \mathrm{~A}$ & $19-20 \mathrm{~A}$ & $15-0 \mathrm{~S}$
\end{tabular}




$\begin{array}{lccccccc}\text { MBSU113 } & 25-26 \mathrm{M} & \text { PG } & 4 \mathrm{~A} & 1 \mathrm{~A} & 5-6 \mathrm{~A} & 10-11 \mathrm{~A} & 15-0 \mathrm{~S} \\ \text { MBSU121 } & 23-24 \mathrm{M} & \text { PD } & 3 \mathrm{M} & 8 \mathrm{~A} & 4-5 \mathrm{~A} & 11-12 \mathrm{~A} & 1015 \mathrm{~S} \\ \text { MBSU128 } & 24-25 \mathrm{M} & \text { PD } & 31 \mathrm{M} & 8 \mathrm{~A} & 4-5 \mathrm{~A} & 14-15 \mathrm{~A} & 25-0 \mathrm{~S} \\ \text { MBSU130 } & 1-2 \mathrm{~A} & \text { HO } & 12 \mathrm{~A} & 12 \mathrm{~A} & 11-13 \mathrm{~A} & 21-22 \mathrm{~A} & 1-10 \mathrm{O} \\ \text { MBSU134 } & 25-26 \mathrm{M} & \text { PG } & 6 \mathrm{~A} & 3 \mathrm{~A} & 1-2 \mathrm{~A} & 9-10 \mathrm{~A} & 15-0 \mathrm{~S} \\ \text { MBSU143 } & 21-22 \mathrm{M} & \text { PD } & 30 \mathrm{M} & 8 \mathrm{~A} & 4-5 \mathrm{~A} & 11-12 \mathrm{~A} & 10-5 \mathrm{~S}\end{array}$

M: March, A: April, PD: Protandrous, PG: Protogynous, HO: Homogamous, S: September, O: October, Dff: Date of the first foliation, Fh: Flower habits, Bdmf: blooming date of male flowers, Bdff: blooming date of female flowers, Dfb: Date of the first budding, Dff: Date of full flowering, Hd: Harvest date

The lowest and the highest Fruit weight (Fw1) in the promising genotypes were determined as $9.67 \mathrm{~g}$ (MBSU128) and 15.68g (MBSU14), respectively (Table 3). The lowest Kernel weight (Kw) was $5.35 \mathrm{~g}$ (MBSU130) while the highest Kernel weight (Kw) was 8.54g (MBSU14). Moreover, the lowest and the highest Kernel ratio (Kr) were found as $48.35 \%$ (MBSU95) and 67.27\% (MBSU128), respectively (Table 3). In this study, the thin Shell thickness (St) was $0.66 \mathrm{~mm}$ (MBSU128) whereas the Shell thickess (St) was $1.40 \mathrm{~mm}$ (MBSU83) (Table 3). This study revealed that the widest fruits $(37.00 \mathrm{~mm})$ were obtained from the MBSU143 genotype, while the narrowest fruits $(28.42 \mathrm{~mm})$ were obtained from MBSU134 genotype (Table 3). Fruit height (Fh) changed between $28.30 \mathrm{~mm}$ (MBSU134) and $36.32 \mathrm{~mm}$ (MBSU14) (Table 3). Fruit length (Fl) was found to be from $33.53 \mathrm{~mm}$ (MBSU130) to $45.78 \mathrm{~mm}$ (MBSU14) (Table 3). In addition, fruit shape (Fs1) was determined as oval and spherical; Shell thickess ( $\mathrm{St}$ ) was determined as very thin, thin and medium; Fruit size (Fs2) was determined as extra; shell roughness (Sr1)was determined as weak, smooth and medium; shell adhesion (Sa) was determined as weak and strong; shell removal ( $\mathrm{Sr} 2$ ) was determined as easy and medium; wholeness ratio of kernel (Wrk) ranged from 80 to $100 \%$; peel color (Pc) was determined as light brown and dark; Kernel color (Kc) was determined as light yellow for all the genotypes (Table 3).

Table 3. Some physical characteristics of the promising walnut genotypes (average 2012-2013)

\begin{tabular}{lccccccc}
\hline Genotype & Fw1 $(\mathbf{g})$ & Kw $(\mathbf{g})$ & $\mathbf{K r}(\boldsymbol{\%})$ & Fl $(\mathbf{m m})$ & Fw2 mm) & Fh $(\mathbf{m m})$ & St $(\mathbf{m m})$ \\
\hline MBSU14 & $15.68 \pm 1.15$ & $8.54 \pm 0.69$ & $54.48 \pm 2.10$ & $45.78 \pm 2.26$ & $36.41 \pm 2.55$ & $36.32 \pm 1.72$ & $1.39 \pm 0.02$ \\
MBSU37 & $13.79 \pm 0.77$ & $7.35 \pm 0.32$ & $53.32 \pm 0.96$ & $39.00 \pm 1.49$ & $34.97 \pm 1.84$ & $35.95 \pm 1.21$ & $1.18 \pm 0.09$ \\
MBSU44 & $13.00 \pm 0.58$ & $6.87 \pm 0.31$ & $52.84 \pm 0.70$ & $40.68 \pm 2.33$ & $34.14 \pm 2.00$ & $34.76 \pm 1.67$ & $1.27 \pm 0.04$ \\
MBSU53 & $12.19 \pm 0.84$ & $6.40 \pm 0.42$ & $52.57 \pm 1.36$ & 37.382 .38 & $34.75 \pm 2.04$ & $34.83 \pm 2.01$ & $1.36 \pm 0.09$ \\
MBSU79 & $11.86 \pm 0.78$ & $6.54 \pm 0.32$ & $55.17 \pm 0.95$ & $36.89 \pm 1.99$ & $33.64 \pm 1.56$ & $33.67 \pm 2.10$ & $1.31 \pm 0.06$ \\
MBSU83 & $10.95 \pm 0.66$ & $5.55 \pm 0.36$ & $50.66 \pm 0.29$ & $38.87 \pm 1.63$ & $32.84 \pm 1.80$ & $35.29 \pm 1.95$ & $1.40 \pm 0.06$ \\
MBSU95 & $12.49 \pm 1.30$ & $6.01 \pm 0.45$ & $48.35 \pm 2.23$ & $42.83 \pm 2.75$ & $34.25 \pm 1.69$ & $33.92 \pm 1.99$ & $1.22 \pm 0.04$ \\
MBSU100 & $12.72 \pm 0.57$ & $7.04 \pm 0.28$ & $55.46 \pm 4.06$ & $38.77 \pm 1.99$ & $34.66 \pm 2.07$ & $34.02 \pm 2.00$ & $1.00 \pm 0.01$ \\
MBSU113 & $11.17 \pm 0.77$ & $6.47 \pm 0.40$ & $56.87 \pm 3.32$ & $39.22 \pm 2.40$ & $30.73 \pm 1.95$ & $31.85 \pm 2.23$ & $1.02 \pm 0.06$ \\
MBSU121 & $11.88 \pm 1.02$ & $6.45 \pm 0.49$ & $54.64 \pm 0.96$ & $36.41 \pm 2.19$ & $33.88 \pm 1.51$ & $32.80 \pm 1.08$ & $1.06 \pm 0.05$ \\
MBSU128 & $9.67 \pm 0.98$ & $6.35 \pm 0.52$ & $67.27 \pm 1.61$ & $35.13 \pm 1.72$ & $31.56 \pm 2.13$ & $32.38 \pm 2.13$ & $0.66 \pm 0.04$ \\
MBSU130 & $11.07 \pm 1.17$ & $5.35 \pm 0.44$ & $48.45 \pm 1.20$ & $33.53 \pm 1.70$ & $31.53 \pm 1.50$ & $31.23 \pm 1.56$ & $1.12 \pm 0.04$
\end{tabular}




\begin{tabular}{lccccccc} 
MBSU134 & $9.98 \pm 1.24$ & $5.46 \pm 0.58$ & $54.81 \pm 0.95$ & $42.56 \pm 2.13$ & $28.42 \pm 2.21$ & $28.30 \pm 1.84$ & $1.06 \pm 0.06$ \\
MBSU143 & $11.60 \pm 0.79$ & $6.73 \pm 0.54$ & $57.98 \pm 1.63$ & $34.03 \pm 2.51$ & $37.00 \pm 1.20$ & $33.70 \pm 2.03$ & $1.25 \pm 0.03$ \\
Mean & 12.00 & 6.51 & 54.49 & 38.65 & 33.48 & 33.50 & 1.16 \\
Min. & 9.0 & 5.00 & 45.88 & 31.90 & 27.00 & 27.00 & .63 \\
Max. & 16.8 & 9.33 & 68.94 & 48.24 & 39.32 & 38.01 & 1.46 \\
S.D. & $1.69 *$ & $0.89 *$ & $4.79^{*}$ & $3.83^{*}$ & $2.75^{*}$ & $2.56^{*}$ & $0.20^{*}$ \\
\hline
\end{tabular}

*statistically significant at 0.05. Fw1. Fruit weight, Kw: Kernel weight, Kr: Kernel ratio, Fl: Fruit length, Fw2: Fruit width, Fh: Fruit height, St: Shell thickness

Table 3. (Continued)

\begin{tabular}{lccccccccc}
\hline Genotype & St & Sr & Fs1 & Fs2 & Pc & Kc & Sa & Sr & (\%) \\
\hline MBSU14 & M & S & O & E & L & Ly & W & E & $90-100$ \\
MBSU37 & T & S & Sp & E & D & Ly & W & E & $90-100$ \\
MBSU44 & M & S & Sp & E & L & Ly & W & M & $80-90$ \\
MBSU53 & M & M & Sp & E & L & Ly & St & E & $80-90$ \\
MBSU79 & M & S & Sp & E & D & Ly & St & E & $90-100$ \\
MBSU83 & M & M & Sp & E & L & Ly & & M & $80-90$ \\
MBSU95 & M & S & O & E & L & Ly & St & E & $90-100$ \\
MBSU100 & T & M & Sp & E & B & Ly & W & E & $80-90$ \\
MBSU113 & T & S & O & E & D & Ly & W & E & $80-90$ \\
MBSU121 & T & S & Sp & E & L & Ly & St & M & $90-100$ \\
MBSU128 & Vt & M & S & E & L & Ly & W & E & $80-90$ \\
MBSU130 & T & S & Sp & E & D & Ly & W & E & $80-90$ \\
MBSU134 & T & S & O & E & L & Ly & St & M & $80-90$ \\
MBSU143 & M & S & Sp & E & B & Ly & W & E & $90-100$ \\
\hline
\end{tabular}

M: Medium, T: Thin, Vt: Very thin, S: Smooth, O:Oval, Sp: Spherical, E: Extra, L:Light, B: Brown, D: Dark, Ly: Light yellow, W: Weak, St: Strong, E: Easy, St: Shell thickness, Sr1. Shell roughness, Fs1: Fruit shape, Fs2: Fruit size, Pc: Peel color, Kc. Kernel color, Sa: Shell adhesion, Sr2: Shell removal, Wrk: Wholeness ratio of kernel

The Crude oil (Co), crude protein (Cp), total carbohydrate (Toc), total ash (Ta) and moisture (Mo) percentages of 14 promising walnut genotypes ranged from 62.25 (MBSU130) to $68.91 \%$ (MBSU44), from 14.92 (MBSU37) to $18.27 \%$ (MBSU83), from 10.21 (MBSU44) to $16.15 \%$ (MBSU130), 1.30 (MBSU130) to 2.09\% (MBSU14) and from 3.11 (MBSU128) to 3.98\%(MBSU95), respectively (Table 4). 
Table 4. Some chemical chaacteristics of the promising walnut genotypes (average 2012-2013)

\begin{tabular}{llllll}
\hline Genotype & Mo $(\%)$ & Ta $(\%)$ & Co $(\%)$ & Cp $(\%)$ & Toc $(\%)$ \\
\hline MBSU14 & $3.26 \pm 0.33$ & $2.09 \pm 0.23$ & $63.91 \pm 1.14$ & $15.39 \pm 0.57$ & $15.37 \pm 1.80$ \\
MBSU37 & $3.601 \pm 0.42$ & $1.86 \pm 0.18$ & $67.00 \pm 0.01$ & $14.92 \pm 1.80$ & $12.63 \pm 2.04$ \\
MBSU44 & $3.45 \pm 0.06$ & $1.84 \pm 0.05$ & $68.91 \pm 0.21$ & $15.60 \pm 0.25$ & $10.21 \pm 0.57$ \\
MBSU53 & $3.63 \pm 0.16$ & $1.86 \pm 0.19$ & $65.42 \pm 0.71$ & $17.89 \pm 0.57$ & $11.21 \pm 0.21$ \\
MBSU79 & $3.41 \pm 0.13$ & $1.76 \pm 0.23$ & $66.99 \pm .41$ & $15.71 \pm 0.98$ & $12.14 \pm 0.35$ \\
MBSU83 & $3.84 \pm 0.11$ & $1.81 \pm 0.07$ & $62.99 \pm 0.54$ & $18.27 \pm 0.92$ & $13.10 \pm 0.42$ \\
MBSU95 & $3.98 \pm 0.02$ & $1.83 \pm 0.07$ & $65.03 \pm 0.14$ & $16.88 \pm 1.20$ & $12.29 \pm 1.29$ \\
MBSU100 & $3.32 \pm 0.08$ & $1.89 \pm 0.06$ & $66.31 \pm 0.84$ & $16.40 \pm 0.85$ & $12.09 \pm 1.67$ \\
MBSU113 & $3.14 \pm 0.18$ & $1.76 \pm 0.24$ & $65.01 \pm 0.16$ & $15.14 \pm 1.22$ & $14.96 \pm 1.48$ \\
MBSU121 & $3.33 \pm 0.06$ & $1.77 \pm 0.11$ & $65.91 \pm 0.28$ & $15.97 \pm 0.25$ & $13.03 \pm 0.35$ \\
MBSU128 & $3.11 \pm 0.06$ & $1.36 \pm 0.36$ & $65.55 \pm 0.57$ & $16.48 \pm 0.20$ & $13.51 \pm 0.47$ \\
MBSU130 & $3.49 \pm 0.18$ & $1.30 \pm 0.37$ & $62.25 \pm 1.14$ & $16.83 \pm 2.41$ & $16.15 \pm 1.46$ \\
MBSU134 & $3.91 \pm 0.08$ & $1.55 \pm 0.05$ & $65.27 \pm 0.99$ & $14.98 \pm 0.88$ & $14.30 \pm 0.03$ \\
MBSU143 & $3.38 \pm 0.39$ & $1.51 \pm 0.27$ & $64.44 \pm 0.59$ & $14.95 \pm 0.12$ & $15.73 \pm 0.83$ \\
Mean & 3.49 & 1.73 & 65.35 & 16.10 & 13.33 \\
Minimum & 3.01 & 1.03 & 61.44 & 13.65 & 9.81 \\
Maximum & 3.99 & 2.25 & 69.05 & 18.92 & 17.18 \\
S.D. & $0.31 *$ & $0.26 *$ & $1.76 *$ & $1.31 *$ & $1.91 *$ \\
\hline
\end{tabular}

*statistically significant at 0.05. Mo: Moisture, Ta: Total ash, Co: Crude oil, Cp: Crude protein, Toc: Total carbohydrate

The Total energy (Toe) values of the promising walnut genotypes ranged from 692.09 (MBSU130) to $723.37 \mathrm{kcal}$ (MBSU44) (Figure 1).

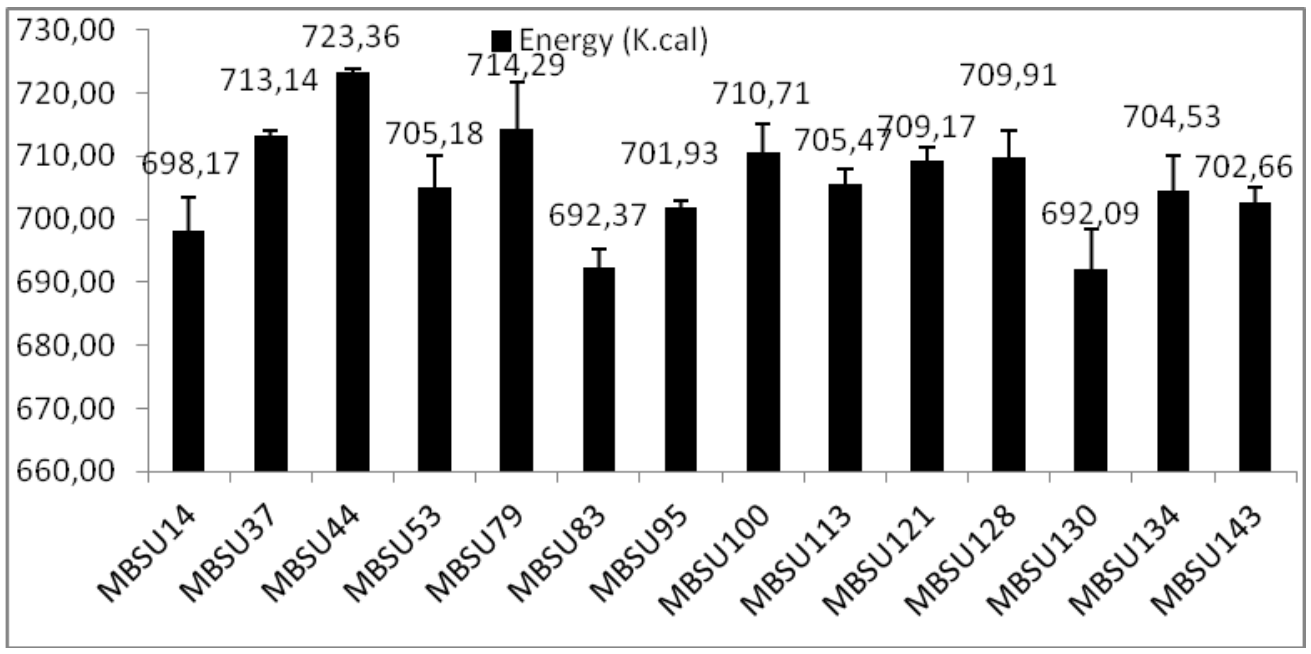

Figure 1. Total energy (Toe) values of the promising walnut genotypes average (2012-2013) 


\section{Discussion}

\section{Some botanical characteristics, fruitful laterals and altitudes of the promosing walnut genotypes}

The fruitful laterals (Frl), date of the first foliation (Dff), blooming date of male flowers (Bdmf), blooming date of female flowers (Bdff), date of the first budding (Dfb), date of full flowering (Dff), Hd and altitude (A) of the promising walnut genotypes (Table 1). The fruitful laterals ( $\mathrm{Frl})$ are the significant factor that determines the potential yield in walnut species. The fruit yield in the lateral shoots were also associated with precocity (Germain, 1999). The percentage of the fruitful laterals ( $\mathrm{Frl}$ ) of Turkish walnut genotypes and cultivars is very low than Californian and French walnut cultivars. The average of percentage of the fruitful laterals ( $\mathrm{Frl}$ ) in Turkish walnut cultivars, Yalova 1', 'Yalova 3', 'Şebin', 'Bilecik', 'Kaman 1', 'Şen 1' 'and 'Bursa 95' were determined to be between 20 and 40\% (Akca, 2012). Akca and Ozongun (2004) observed as from 10 to $70 \%$ for the fruitful laterals (Frl) of the promising walnut genotypes in Ermenek district of Karaman province. Simsek (2010a) was determined that the fruitful laterals ( $\mathrm{Frl}$ ) changed from 75 and $90 \%$ of the selected types. Study results according to fruitless laterals (Frl) were partly different from those of the researchers. The fruitful laterals (Frl) of walnut genotypes and cultivars can change according to the genetic characteristics and the ecological conditions. In addition, Akca et al. (2015) observed that the superior walnut genotypes were found to be resistant to anthrachnosis, bacterial blight and codling moth in Kemah district in Eastern Anatolia of Turkey. The results obtained in this study are in agreement with Akca et al. (2015). Akca and Sen (2001) determined that average age (Aey) of the promising walnut genotypes changed from 35 to 40 years. Simsek et al. (2010) determined that the branching height (Bh), trunk circumferences (Tc) and age (Aey) of the promising walnut types of the promising genotypes from Diyarbakir and Mardin central districts were changed from 200 to $450 \mathrm{~cm}$, from 55 to $380 \mathrm{~cm}$ and from 10 to 80 years, respectively. In the same survey, it was observed that the tree habits (Th) of the genotypes were determined to be erect for 3 genotypes, semi-erect for 3 genotypes, weeping for 3 genotypes, spreading for 2 genotypes and open for 1 genotype. Many studies have been carried out dealing with the botanical characteristics of walnut genotypes and cultivars in different region of Turkey (Akca and Ozongun, 2004; Akca et al., 2015; Sen, 1986; Simsek, 2010a, 2010b; Simsek and Osmanoglu, 2010; Simsek et al., 2010). The results of botanical characteristics and Fl of walnut genotypes are in agreement with most studies in the literatures.

\section{Some phenological characteristics of promosing walnut genotypes}

Some phenological characteristics of the promosing walnut genotypes were presented in Table 2. Akca and Ozongun (2004) observed as from 15 April to 10 May for the bloom period (Bp) of the promising walnut genotypes in Ermenek district of Karaman province. Simsek (2010a) was determined that the date first foliation (Dff), blooming date of male (Bdmf) and female flowers (Bdff), date of first bud breaking (Dfb), date of full flowering (Dff) and Harvest date (Hd) of the selected types in Sanliurfa population changed from 21 March to 28 March, from 30 March to 6 April, from 29 March to 7 April, from 26 March to 6 April, from 3 April to 12 April and from 5 September to 20 September, respectively. Oguz and Askin (2007) studied on first leafing time, the lower habits, blooming date of the male (Bdmf) and the female flowers 
(Bdff), date of the first bud breaking (Dfb) and the date of full flowering (Dff) and Harvest date $(\mathrm{Hd})$ of the walnut types in Ermenek and finally they (Oguz and Askin, 2007) observed the similar results like Simsek (2010a). In addition, He (2010a) determined that the protandrous and the protogynous of these types in Sanliurfa province observed as $63.63 \%$ and $33.37 \%$, respectively. Simsek (2010b) determined that the protandrous, protogynous and homogynous of 17 promising walnut genotypes in Cermik and Cungus populations in Southeast Anatolia observed as 6, 4 and 2, respectively. Beyhan and Ozatar (2007) observed that the flowering habit (Fh) of the selected types determined as $58.59 \%$ protandrous, $28.30 \%$ protogynous and $13.20 \%$ homogomous in Kahramanmaraş province. Gulsoy et al. (2016) observed that the protandrous, protogynous and homogynous of 21 promising walnut genotypes in Iğdır central district and its villages observed as 11, 9 and 1, respectively. The botanical chaacteristics of walnut genotypes and cultivars can vary with the year of harvest, environmental conditions, horticultural practices and genetic characteristics.

\section{Some physical characteristics of the promising walnut genotypes}

Some physical chaacteristics of the promising genotypes were presented in Table 3. Polat et al. (2015) carried out as 10.42-14.25 g fruit weight (Fw1), 4.52-7.44 g kernl weight (Kw), 42.38-54.07\% kernel ratio (Kr) and 1.20-1.80 mm shell thickness (St) for 17 promising genotypes in Bitlis province. Gulsoy et al (2015) determined that the fruit weight (Fw1), kernl weight $(\mathrm{Kw})$, kernel ratio (Kr), fruit width (Fw2), fruit height $(\mathrm{Fh})$, fruit length (Fl) and shell thickness (St) of walnut genotypes in the villages located in the Tuzluca district of the Igdir province changed from 10.12-13.22 g, 5.00-6.07 g, 40.01-52.63\%, 30.67-34.75 mm, 29.75-35.52 mm, 31.78-44.38 mm and 1.46-2.46 mm, respectively. Gulsoy et al. (2016a) determined that fruit weight (Fw1), kernl weight $(\mathrm{Kw})$, kernel ratio $(\mathrm{Kr})$ and shell thickness $(\mathrm{St})$ of the superior walnut genotypes from Iğdır central district and its villages were changed from $10.04-15.77 \mathrm{~g}, 5.57-7.46 \mathrm{~g}$, 42.87-59.62\% and 1.25-3.10 mm, respectively. Simsek and Osmanoglu (2010) determined that superior walnut genotypes in Mazidagi district had fruit length $(\mathrm{Fl})$ 35.64-42.02 mm, fruit width (Fw2) 29.78-34.46 mm, fruit hight (Fh) 29.69-35.56 mm, extra fruit size (Fs2) for all the genotypes studied according to Turkish standards. Akca and Sen (2001) determined that the fruit weight (Fw1), the kernel weight (Kw), the shell thickness (St), the fruit width (Fw2) and the fruit length (Fl) changed from 13.93 to 7.49 $\mathrm{g}$, from 5.73 to $2.61 \mathrm{~g}$, from 2.45 to $1.32 \mathrm{~mm}$, from 32.26 to $22.30 \mathrm{~mm}$ and from 49.25 to $32.90 \mathrm{~mm}$, respectively. Kuden et al. (1995) determined the kernel ratio (Kr) changed from 41.44 to $56.25 \%$. Beyhan and Ozatar (2007) determined to be fair or smoorh of shell roughness $(\mathrm{Sr} 1)$, dark or light of peel color $(\mathrm{Pc})$, light yellow, yellow, yellow brown and brown of Kernel color $(\mathrm{Kc})$ of the selected types in Kahramanmaras province. The values obtained on physical characteristics in this study were in agreement with the values found in similar studies conducted in Turkey (Beyhan and Ozatar, 2007; Kuden et al., 1995; Oguz and Askin, 2007; Polat et al., 2015; Simsek and Osmanolu, 2010; Gulsoy et al., 2015; Gulsoy et al., 2016a).

\section{Some chemical characteristics of the promising walnut genotypes}

Some chemical characteristics of the promising walnut genotypes were presented in Table 4. Ozkan and Koyuncu (2005) reported that 10 walnut genotypes from Turkey contained 1.26-2.06 total ash (Ta), 61.97-70.92\% crude oil (Co), 15.17-19.24\% crude 
protein (Cp) and 3.25-3.91\% moisture (Mo). Pereira et al. (2008) showed that six walnut cultivars from Portugal contained 3.31-4.26\% total ash (Ta), 68.83-72.14\% crude oil (Co), 14.38-18.03\% crude protein (Cp) and 3.85-4.50\% moisture (Mo). Oguz and Askin (2007) determined that crude protein (Cp), crude oil (Co), moisture (Mo) and total ash (Ta) content of the walnut genotypes changed from 12.11 to $20.75 \%$, from 54.07 to $67.63 \%$, from 2.70 to $3.79 \%$ and from 1.00 to $2.22 \%$, respectively. Ali et al. (2010) determined that promising walnut cultivars from Pakistan ranged from 63.54 to $69.25 \%$ crude oil (Co), from 15.96 to $19.15 \%$ crude protein $(\mathrm{Cp})$, from 8.04 to $1.14 \%$ total carbohydrate (Toc), from 1.27 to $1.95 \%$ total ash (Ta) and from 2.76 to $4.20 \%$ moisture (Mo). Simsek (2010a) reported that total ash (Ta), crude oil (Co), crude protein $(\mathrm{Cp})$ and moisture (Mo) contents of the selected walnut genotypes in Turkey ranged from 1.88 to $2.89 \%, 58.88$ to $65.64 \%, 13.70$ to $20.18 \%$ and 1.63 to $4.73 \%$, respectively. Yerlikaya et al. (2012) also found that total ash (Ta), crude oil (Co), crude protein $(\mathrm{Cp})$ and moisture $(\mathrm{Mo})$ contents of walnut genotypes in Western Anatolia ranged from 1.53 to $1.99 \%$, from 61.32 to $69.35 \%$, from 10.58 to $18.19 \%$ and from 1.91 to $4.48 \%$, respectively. Akca et al. (2015) reported that total ash (Ta), crude oil (Co) and crude protein $(\mathrm{Cp})$ contents of 9 promising walnut selections in Kemah district of Turkey ranged from 1.50 to $2.27 \%, 55.18$ to $65.70 \%$ and 14.70 to $20.10 \%$, respectively. Gulsoy et al. (2016b) determined that the crude oil (Co), crude protein (Cp), total ash (Ta) and moisture (Mo) ratios of walnut genotypes of Tuzluca (Igdir) district varied in a range of $50.52-66.68 \%, 6.59-26.57 \%, 0.98-4.00 \%$ and $2.55-6.98 \%$, respectively. Gulsoy et al. (2016c) determined that the crude oil (Co), crude protein (Cp), total ash (Ta) and moisture (Mo) content of selected walnut genotypes from Iğdır province varied from 50.03 to $64.98 \%, 10.23$ to $22.14 \%, 0.97$ to $3.96 \%$ and 3.05 to $4.48 \%$, respectively. The results of the crude oil $(\mathrm{Co})$, crude protein $(\mathrm{Cp})$, total ash $(\mathrm{Ta})$ and moisture (Mo) content of our selected walnut genotypes are mostly in agreement with previous studies. The walnut genotypes and cultivars had as high crude protein (Cp) levels as some legumes such as peas, chickpeas and lentils. The total carbohydrate (Toc) values of walnut genotypes and cultivars in previous studies were found in the range of $7.04-$ 23.80\% (Simsek et al., 2010), 8.05-13.23\% (Ozkan and Koyuncu), 3.75-7.16\% (Pereira et al., 2008) and 8.04-12.41\% (Ali et al., 2010).

Toe values of the promising walnut genotypes were presented in Figure 1. The total energy (Toe) values of walnut genotypes and cultivars are quite high. Total energy (Toe) values of walnut genotypes and cultivars in previous studies were found in the range of 682.0-728.0 kcal (Yerlikaya et al., 2012), 698.10-732.44 kcal (Ali et al., 2010) and 686.2 to $710 \mathrm{kcal}$ (Simsek, 2016). The energy levels of the walnut genotypes are in agreement with other studies. The energy levels are attributable to differences in the chemical compositions of various walnut types and cultivars and may vary with the year of harvest, environmental conditions, horticultural practices, and genetics.

\section{Conclusion}

In this study, some botanical, phenological, physical and chemical characteristics of the promising walnut genotypes grown from seed in Beyazsu region of Mardin province of Turkey were investigated. The results obtained in this study were consistent with the values reported by other researchers. Kernels of MBSU83 genotype were determined to contain high crude protein $(\mathrm{Cp})$ content $(>18 \%)$ while all the genotypes contain high carbohydrate (Toc) content $(>10 \%)$. The data reported in this study confirm that walnuts 
are a rich source of a number of significant nutrients. The results of the present study are expected to contribute to breeding studies and may help improve economically sustainable walnut production for the farmers of Southeastern Turkey in future.

\section{REFERENCES}

[1] Akca, Y. (2012): Walnut growing. - Anit press, Ankara, Turkey (in Turkish).

[2] Akca, Y., Ozgen, M., Erturk, U., Ercisli, S. (2012): The effects of AVG and GA treatments on pistillate (female) flower abortion in 'Sebin' walnut cultivar. - Acta Scientiarum Polonorum Hortorum Cultus 11(4): 179-185.

[3] Akca, Y., Sen, S. M. (2001): A study on the genetic variability and selection of promising walnut (Juglans regia L.) trees within seedlıng population of around of Van Lake. Proc. IV Int. Walnut Symp. - Acta Hort., 544.

[4] Akca, Y., Ozongun, S. (2004): Selection of late leafing, late flowering, laterally fruitful walnut (Juglans regia L.) types in Turkey. - New Zealand Journal of Crop and Horticultural Science 32 (4): 337-342.

[5] Akca, Y., Bilgen, Y., Ercisli, S. (2015): Selection of promising persian walnut (Juglans regia L.) from seedlıng origin in Turkey. - Acta Scientiarum Polonorum Horticulture 14 (3): 103-114.

[6] Ali, M., Ullah, A., Ullah, H., Khan, F., Ibrahim, S.M., Ali, L., Ahmad, S. (2010): Fruit properties and nutritional composition of some walnut cultivars grown in Pakistan. Pakistan Journal of Nutrition 9 (3): 240-244.

[7] AOAC. (1990): Official methods of analysis. 15th AOAC International. Washington. DC, USA.

[8] AOAC. (1995): Association of official agricultural chemists. Official methods of analysis. 16th ed. Washington DC USA.

[9] Anonymous (1994): Description for walnut (Juglans regia L.). Int. - Plant Genetic Resources Institute, p. 51, Rome, Italy.

[10] Anonymous (2015): http://tr.climate-data.org/location/288/.(Accessed on 25.12.2016)

[11] Anonymous (2016): https://www.google.com.tr/webhp?sourceid=chrome-instant \&ion=1\&espv=2\&ie=UTF-8\#q=google\%20earth\%20professional. (Accessed on 25.12.2016).

[12] Askin, M. A., Gun, A. (1995): Researchs by breeding of Cameli and Bozkurt walnuts (Juglans regia L.) research on breeding through selection of walnuts. - Turkey II. National Horticulture Congress, Adana, Tukey, pp. 461-463.

[13] Bakkalbasi, E., Yilmaz, O.M., Artik, N. (2010): Physical properties and chemical composition of some walnut cultivars grown in Turkey. - Akademik Gida 8 (1): 6-12.

[14] Beyhan, O., Ozatar, H. O. (2007): Breeding by Selection of Walnuts (Juglans regia L.) in Kahramanmaras. - International Journal of Natural and Engineering Sciences 2 (3): 93-97.

[15] Ercisli, S., Kara, M., Ozturk, I., Sayinci, B., Kalkan, F. (2011): Comparison of some physicomechanical nut and kernel properties of two walnut (Juglans regia L.) cultivars. - Notulae Botanicae Horti Agrobotanici Clij-Napoca 39 (2): 227-231.

[16] FAO. (2013): Walnut production statistics. Available at: http://faostat3.fao.org. (Accessed on 25.12.2016).

[17] Germain, E. (1999): Le Noyer. - INRA, Bordeaux, France.

[18] Gulsoy, E., Tuncay, K., Simsek, M., Pehluvan, M. (2016a): Selections of Walnut (Juglans regia L.) in Igdır District. Iğdır Univ. - J. Inst. Sci. \& Tech. 6(1): 25-30 (in Turkish).

[19] Gulsoy, E., Kaya, T., Turkhan, A. (2016b): Physico-Chemical Characterization of Walnut Genotypes of Tuzluca (Igdir) District. - Journal of Agricultural Faculty of Gaziosmanpasa University 33 (2): 166-173 (in Turkish). 
[20] Gülsoy, E., Kaya, T., Pehluvan, M., Şimşek, M. (2016c): Some pomological properties and chemical contents of selected walnut (Juglans regia L.) genotypes from Igdir Province. - Anadolu J. Agr. Sci. 31 (3): 309-314 (in Turkish).

[21] Gulsıy, E., Kaya, T., Pehluvan, M., Doğru, B., Bozhöyük, R. (2015): Selectıon of Naturally Grown Walnuts of the Valley Hamurkesen Regıon of Tuzluca (Iğdır) District. - Bahçe (Special issue): Reports of the 7th National Horticulture Congress, Volume 1: Orcharding, pp. 360-364.

[22] Jung, S., Rickert, D.A., Deak, N.A., Aldin, E.D., Recknor, J., Johnson, L.A., Murphy, P. A. (2003): Kjeldahl and dumas methods for determining crude protein contents of soybean products. - Journal of the American Oil Chemists' Society 80 (12): 1169-1173.

[23] Kazankaya, A., Balta, M. F., Yoruk, I. H., Balta, F., Battal, P. (2008): Analysis of sugar composition in nut crops. Asian Journal of Chemistry, 20 (2): 1519-1525.

[24] Koyuncu, M. M., Ekinci, K., Savran, E. (2004): Cracking characteristics of walnut. Biosystems Engineering 87 (3): 305-311.

[25] Kuden, A., Kaska, N., Turemis, N. (1995): Walnut selection in middle taurus mountains. - III. International Walnut Congress, 13-16 June, 1995, Alçobaça, Portugal. Acta Horticulturae, 442: 117-119.

[26] Muradoglu, F., Balta, F. (2010): Some physical and chemical characteristics of promising walnuts (Juglans regia L.) genotypes selected from Ahlat (Bitlis). - YYU J. Agric. Sci. 20 (1): 41-45 (in Turkish).

[27] Oguz, H. A., Askin, A. (2007): A study on the selection of walnut (Juglans regia L.) in Ermenek. - YYU. J. Agric. Sci. 17 (1): 21-28 (in Turkish).

[28] Ozkan, G., Koyuncu, M.A. (2005): Physical and chemical composition of some walnut (Juglans regia L) genotypes grown in Turkey. - Grasas y Aceites 56 (2): 141-146.

[29] Pereira, J. A., Oliveira, L., Sousa, A., Ferreira, L.C.F.R., Bento, A., Estevinho, L. (2008): Bioactive properties and chemical composition of six walnut (Juglans regia L.) cultivars. - Food and Chemical Toxicology 46: 2103-2111.

[30] Polat, M., Okatan, V., Güclü, F. (2015): Determination of some physical and chemical properties of walnut (Juglans regia l.) genotypes grown in the central district of Bitlis/Turkey. - Scientific Papers. Series B. Horticulture, LIX: 81-6.

[31] Savage, G. P. (2001): Chemical composition of walnuts grown in New Zealand. - Plant Foods for Human Nutrition 56: 75-82.

[32] Sen, S. M. (1986): Walnut production. - Eser Press (in Turkish), Samsun, 109-129 (in Turkish).

[33] Simsek, M. (2010a): Selection of walnut types with high fruit bearing and quality in Sanliurfa population. - International Journal of Physical Sciences 5: 992-996.

[34] Simsek, M. (2010b): Physical and chemical properties of promising walnut types in Cermik and Cungus populations. - International Journal of Natural and Engineering Sciences 4: 29-34.

[35] Simsek, M. (2016): Chemical, mineral, and fatty acid compositions of various types of walnut (Juglans regia L.) in Turkey. - Bulgarian Chemical Communications 48(1): 6670 .

[36] Simsek, M., Osmanoglu, A. (2010): Selection of native walnuts (Juglans regia 1.) in Mazidagi district (Mardin). - YYU Ziraat Fakültesi Tarım Bilimleri Dergisi (YYU. J. Agric. Sci.) 20: 131-137.

[37] Simsek, M., Yilmaz, K.U., Demirkiran, A.R. (2010): Selection and determination of some significant properties of promising walnut genotypes. - Scientific Research and Essays 5: 2987-2996.

[38] TSE. (1990): Unshelled walnuts. - Turkish Standard Institute (T.S.E.), TS 1275, Ankara, Turkey.

[39] TSE. (1991): Walnut kernels. - Turkish Standard Institute (T.S.E.), TS 1276, Ankara, Turkey. 
[40] Unver, H., Celik, M. (2005): Studies on varietal selection in walnut (Juglans regia L.) populations of Ankara province. - BAHÇE Ceviz 34: 83-89.

[41] Yerlikaya, C., Yucel, S., Erturk, U., Korukluoglu, M. (2012): Proximate composition, minerals and fatty acid composition of Juglans regia L. genotypes and cultivars grown in Turkey. - Brazilian Archives of Biology and Technology 55: 677-683. 